\title{
Teaching Video NeuroImage: "Weighing" in on an Unusual Tremor
}

Marta Villa-López, MD, Eungseok Oh, MD, PhD, Robert Chen, MD, Anthony E. Lang, MD, FRCPC, Mario Masellis, MSc, MD, PhD, FRCPC,* and Julia J. Hopyan, MD, FRCPC*

Neurology ${ }^{\circledR}$ 2021;97:e970-e971. doi:10.1212/WNL.0000000000012141

Figure Electrophysiologic Studies

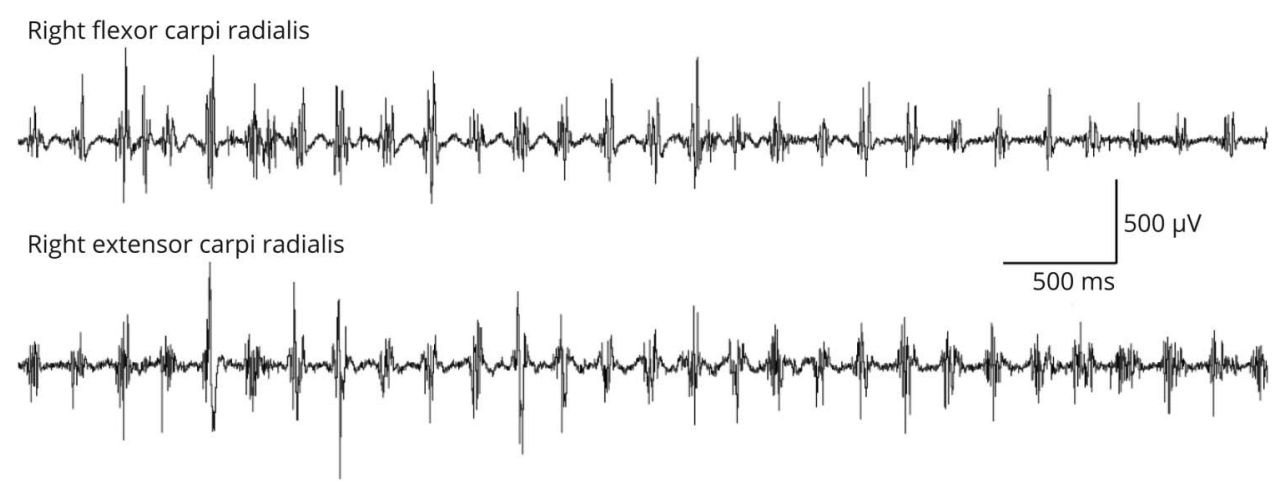

Surface EMG recording of 6-Hz tremor in the right flexor carpi radialis and extensor carpi radialis muscles while holding a bag (weight $\sim 2.3 \mathrm{~kg}$ ), with the hand in a "semi-opened" position. There was synchronous activation of agonist-antagonist muscles, which was specific to carrying weight in the right arm.

A 73-year-old right-handed man with hypertension, hypercholesterolemia, renal insufficiency, and cyclothymic disorder presented with 1 year of insidious onset tremor in his right hand when carrying his briefcase. Psychotropic drugs included bupropion and lamotrigine. He was neurologically intact except for a very low amplitude bilateral kinetic tremor $(\mathrm{L}>\mathrm{R})$ and a much larger amplitude right hand task-specific tremor (video 1) characterized by EMG (figure).

The phenomenology is classic for a weight-holding or "shopping bag tremor" first described in 1995. ${ }^{1}$ It is difficult to categorize based on the consensus statement for tremor classification. ${ }^{2}$ It could be considered a variant of isometric tremor, essential tremor, or task-specific tremor with different underlying etiologies. It is typically an asymmetric, progressive kinetic tremor that appears exclusively (or is more evident) when holding a weight, in contrast to classical essential tremor, which reduces in amplitude with weight-bearing.

\section{Acknowledgment}

The authors thank the patient for participation.

\section{Study Funding}

No targeted funding reported.

\author{
Correspondence \\ Dr. Masellis \\ mario.masellis@ \\ sunnybrook.ca
}

MORE ONLINE

Video

Teaching slides

http://links.lww.com/

$\mathrm{WNL} / \mathrm{B} 398$

*These authors participated equally as co-senior authors.

From the Hurvitz Brain Sciences Program (M.V.-L., M.M.), Sunnybrook Research Institute, Toronto; Edmond J. Safra Program in Parkinson's Disease (E.O., R.C., A.E.L.) and Morton and Gloria Shulman Movement Disorders Clinic (R.C., A.E.L.), Toronto Western Hospital, University Health Network; Division of Neurology (M.V.-L., R.C., A.E.L., M.M., J.J.H.), Department of Medicine, University of Toronto; and Cognitive \& Movement Disorders Clinic (M.M.) and Regional Stroke Centre (.J.H.), Sunnybrook Health Sciences Centre, Toronto, Ontario, Canada. Go to Neurology.org/N for full disclosures. Funding information and disclosures deemed relevant by the authors, if any, are provided at the end of the article. 


\section{Disclosure}

M. Villa-López and O. Eungseok report no disclosures relevant to the manuscript. $\mathrm{R}$. Chen serves as Editor-in-Chief of the Canadian Journal of Neurologic Sciences, received honorarium from Allergen, Merz, and Ipsen, consulted for NeuroQore, and received research support from the Canadian Institutes of Health Research, National Institute of Neurologic Disorders and Stroke, Canada Foundation for Innovation, Ontario Research Fund, National Science and Engineering Research Council of Canada, Dystonia Medical Research Foundation, Weston Brain Foundation, and National Organization for Rare Disease, outside the submitted work. A.E. Lang reports consultancy support from AbbVie, Acorda, AFFiRis, Biogen, Denali, Janssen, Intracellular, Kallyope, Lundbeck, Paladin, Retrophin, Roche, Sun Pharma, Theravance, and Corticobasal Degeneration Solutions; advisory board support form Jazz Pharma, PhotoPharmics, and Sunovion; other honoraria from Sun Pharma, AbbVie, Sunovion, American Academy of Neurology, and the International Parkinson and Movement Disorder Society; grants from Brain Canada, Canadian Institutes of Health Research, Corticobasal Degeneration Solutions, Edmond J. Safra Philanthropic Foundation, Michael J. Fox Foundation, the Ontario Brain Institute, Parkinson Foundation, Parkinson Canada, and W. Garfield Weston Foundation; and royalties from Elsevier, Saunders, Wiley-Blackwell, Johns Hopkins Press, and Cambridge University Press outside the submitted work. M. Masellis reports advisory board support from Arkuda Therapeutics, Ionis Pharmaceuticals, Alector Pharmaceuticals, Wave Life Sciences, and Biogen Canada; royalties from Henry Stewart Talks Ltd; and grants paid to the institution from Roche, Alector, Weston Brain Institute, Ontario Brain Institute, and the Canadian Institutes of Health Research outside the submitted work. J. Hopyan reports royalties from Elsevier outside the submitted work. Go to Neurology.org/N for full disclosures.

Appendix Authors

\begin{tabular}{lll}
\hline Name & Location & Contribution \\
\hline $\begin{array}{lll}\text { Marta Villa- } \\
\text { López, MD }\end{array}$ & $\begin{array}{l}\text { Hurvitz Brain Sciences } \\
\text { Program, Sunnybrook } \\
\text { Research Institute; Division } \\
\text { of Neurology, Department } \\
\text { of Medicine, University of } \\
\text { Toronto, Canada }\end{array}$ & $\begin{array}{l}\text { Drafting/revision of the } \\
\text { manuscript for content, } \\
\text { including medical writing } \\
\text { for content; major role in } \\
\text { the acquisition of data; } \\
\text { study concept or design }\end{array}$ \\
\hline
\end{tabular}

Appendix (continued)

\begin{tabular}{|c|c|c|}
\hline Name & Location & Contribution \\
\hline $\begin{array}{l}\text { Eungseok Oh, } \\
\text { MD, PhD }\end{array}$ & $\begin{array}{l}\text { Edmond J. Safra Program in } \\
\text { Parkinson's Disease, } \\
\text { Toronto Western Hospital, } \\
\text { University Health Network, } \\
\text { Canada }\end{array}$ & $\begin{array}{l}\text { Drafting/revision of the } \\
\text { manuscript for content, } \\
\text { including medical writing } \\
\text { for content; major role in } \\
\text { the acquisition of data; } \\
\text { study concept or design }\end{array}$ \\
\hline $\begin{array}{l}\text { Robert Chen, } \\
\text { MD }\end{array}$ & $\begin{array}{l}\text { Division of Neurology, } \\
\text { Department of Medicine, } \\
\text { University of Toronto; } \\
\text { Edmond J. Safra Program in } \\
\text { Parkinson's Disease, } \\
\text { Toronto Western Hospital, } \\
\text { University Health Network; } \\
\text { Morton and Gloria Shulman } \\
\text { Movement Disorders Clinic, } \\
\text { Toronto Western Hospital, } \\
\text { University Health Network, } \\
\text { Canada }\end{array}$ & $\begin{array}{l}\text { Drafting/revision of the } \\
\text { manuscript for content, } \\
\text { including medical writing } \\
\text { for content; major role in } \\
\text { the acquisition of data; } \\
\text { study concept or design }\end{array}$ \\
\hline $\begin{array}{l}\text { Anthony E. } \\
\text { Lang, MD, } \\
\text { FRCPC }\end{array}$ & $\begin{array}{l}\text { Division of Neurology, } \\
\text { Department of Medicine, } \\
\text { University of Toronto; } \\
\text { Edmond J. Safra Program in } \\
\text { Parkinson's Disease, } \\
\text { Toronto Western Hospital, } \\
\text { University Health Network; } \\
\text { Morton and Gloria Shulman } \\
\text { Movement Disorders Clinic, } \\
\text { Toronto Western Hospital, } \\
\text { University Health Network, } \\
\text { Canada }\end{array}$ & $\begin{array}{l}\text { Drafting/revision of the } \\
\text { manuscript for content, } \\
\text { including medical writing } \\
\text { for content; major role in } \\
\text { the acquisition of data; } \\
\text { study concept or design }\end{array}$ \\
\hline $\begin{array}{l}\text { Mario } \\
\text { Masellis, MSc, } \\
\text { MD, PhD, } \\
\text { FRCPC }\end{array}$ & $\begin{array}{l}\text { Hurvitz Brain Sciences } \\
\text { Program, Sunnybrook } \\
\text { Research Institute, Toronto; } \\
\text { Division of Neurology, } \\
\text { Department of Medicine, } \\
\text { University of Toronto; } \\
\text { Cognitive \& Movement } \\
\text { Disorders Clinic, } \\
\text { Sunnybrook Health Sciences } \\
\text { Centre, Toronto, Canada }\end{array}$ & $\begin{array}{l}\text { Drafting/revision of the } \\
\text { manuscript for content, } \\
\text { including medical writing } \\
\text { for content; major role in } \\
\text { the acquisition of data; } \\
\text { study concept or design }\end{array}$ \\
\hline $\begin{array}{l}\text { Julia Jasmine } \\
\text { Hopyan, MD, } \\
\text { FRCPC }\end{array}$ & $\begin{array}{l}\text { Division of Neurology, } \\
\text { Department of Medicine, } \\
\text { University of Toronto; } \\
\text { Regional Stroke Centre, } \\
\text { Sunnybrook Health Sciences } \\
\text { Centre, Toronto, Canada }\end{array}$ & $\begin{array}{l}\text { Drafting/revision of the } \\
\text { manuscript for content, } \\
\text { including medical writing } \\
\text { for content; major role in } \\
\text { the acquisition of data; } \\
\text { study concept or design }\end{array}$ \\
\hline
\end{tabular}

\section{References}

1. Lang AE, Jog M, Ashby P. "Weight-holding tremor": an unusual task-specific form of essential tremor? Mov Disord. 1995;10(2):228-229.

2. Bhatia KP, Bain P, Bajaj N, et al. Consensus statement on the classification of tremors: from the task force on tremor of the International Parkinson and Movement Disorders Society. Mov Disord. 2018;33(1):75-87. 


\section{Neurology}

\section{Teaching Video NeuroImage: "Weighing" in on an Unusual Tremor \\ Marta Villa-López, Eungseok Oh, Robert Chen, et al.}

Neurology 2021;97;e970-e971 Published Online before print April 30, 2021

DOI 10.1212/WNL.0000000000012141

This information is current as of April 30, 2021

\section{Updated Information \&} Services

References

Subspecialty Collections

Permissions \& Licensing

Reprints including high resolution figures, can be found at: http://n.neurology.org/content/97/9/e970.full

This article cites 2 articles, 0 of which you can access for free at: http://n.neurology.org/content/97/9/e970.full\#ref-list-1

This article, along with others on similar topics, appears in the following collection(s):

All global neurology

http://n.neurology.org/cgi/collection/all_global_neurology Tremor

http://n.neurology.org/cgi/collection/tremor

Information about reproducing this article in parts (figures,tables) or in its entirety can be found online at:

http://www.neurology.org/about/about_the_journal\#permissions

Information about ordering reprints can be found online:

http://n.neurology.org/subscribers/advertise

Neurology ${ }^{\circledR}$ is the official journal of the American Academy of Neurology. Published continuously since 1951, it is now a weekly with 48 issues per year. Copyright @ 2021 American Academy of Neurology. All rights reserved. Print ISSN: 0028-3878. Online ISSN: 1526-632X.

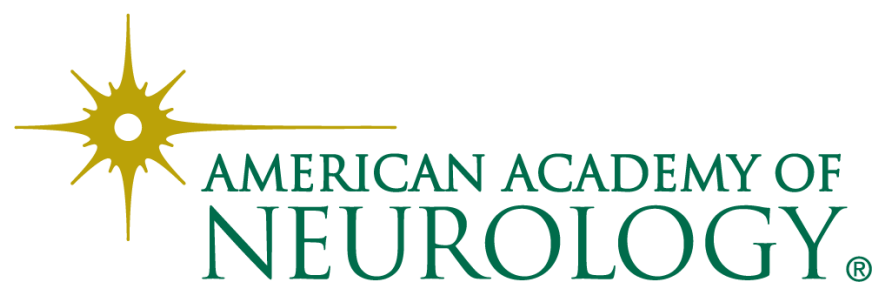

